Acta medico-historica Rigensia (2020) XIII: 09-28

doi:10.25143/amhr.2020.XIII.02

I. PĒTNIECISKIE RAKSTI

Stella Hermanovska

\title{
Garīgās nespējas reprezentācija sociālās aprūpes kontekstā Latvijas teritorijā 19. gadsimta otrajā pusē
}

\section{Anotācija}

Par pavērsiena punktu speciālās izglītības un sociālās aprūpes vēsturē Latvijā ir uzskatāms 1854. gads, kad Rīgā tika dibināta pirmā iestāde bērniem ar garīgās attīstības traucējumiem. Nozīmīgi tās darbības izpētes avoti ir 1862. gadā izdotais fotogrāfiju albums "Idioten-Anstalt von Fr. Platz: Riga d. 9. Juli” 1862 un ziņojumi par iestādes darbību. Rakstā ir sniegts izklāsts par speciālās izglītības un sociālās aprūpes aizsākumu 19. gadsimtā Latvijas teritorijā (toreizējā Krievijas Impērijā, Vidzemes guberṇā) personām ar garīgās attīstības traucējumiem un par to reprezentāciju, pievēršot uzmanību priekšstata radīšanai par sociālo grupu medicīniskā diskursā un medicīnisko tekstu un fotogrāfijas izplatībai informatīvajā telpā êtikas un konfidencialitātes kontekstā.

Raksta mērķis ir raksturot nozares institucionālās attīstības aizsākumus un noskaidrot, kā Rīgā pirmās speciālās izglītības un aprūpes iestādes tekstuālā un fotogrāfiskā dokumentācija ir izmantota garīgo traucējumu reprezentācijai no 19. gadsimta otrās puses publicitātes un mūsdienu medicīniskās informācijas konfidencialitātes perspektīvām.

Rakstam izvirzītie uzdevumi: 1) apzināt un raksturot Frīdriha un Terēzes Placu darbību speciālās izglìtības un sociālās aprūpes institucionalizācijas kontekstā, 2) noskaidrot institucionālās prakses garīgās nespējas diskursu un fotogrāfijas nozīmi garīgās nespējas dokumentācijā un reprezentācijā un 3) salīdzināt medicīniska satura tekstu un fotogrāfiju izplatību informatīvajā telpā ētikas un konfidencialitātes kontekstā no 19. gadsimta otrās puses un mūsdienu skatpunkta, pretstatot pacientu anonimitāti un privātumu ar publisku reprezentāciju. 
Pētījums ir veikts valsts pētîjumu programmas "Latvijas mantojums un nākotnes izaicinājumi valsts ilgtspējai" projekta "Dokumentārā mantojuma izpētes nozīme, veidojot sinergijas starp pētniecību un sabiedrību" (Nr. VPP-IZM-2018/1-0022) ietvaros.

Atslēgvārdi: sociālā aprūpe, speciālā izglīî̉ba, garīgā nespēja, medicīniskā fotogrāfija, Terēze Placa, Frīdrihs Placs.

\section{Ievads}

Intelektuālo spēju idejai un ar to saistītiem konceptiem, kas l̦auj iedalīt cilvēkus pēc noteiktiem kritērijiem definētās grupās, ir samērā nesena pagātne. Ir pieņemts uzskatīt, ka intelektuālā nespēja ir pastāvīga, vēsturiski nosacìta parādība, ko visas sabiedrības viennozīmīgi atpazītu, ${ }^{1}$ taču laika gaitā starptautiskā līmenī bija vērojama diagnožu terminoloǵijas un klasifikācijas maiņa, kas liecināja par garīgās veselības nozares attīstību. Vēl 19. gadsimta otrajā pusē garīgās nespējas koncepts un institucionāla vara pār tiem, kam tā diagnosticēta, medicīnas un pedagoǵijas jomā bija pārejas procesā. Neņemot to vērā, garīgās nespējas koncepts bija ieviests medicīniskajā praksē līdzās citām slimībām un veselības traucējumiem pēc gadsimtiem ilgas ignorēšanas. Šādas pieejas rezultātā bija vērojams garīgās nespējas institucionalizācijas aizsākums un tās reprezentācija sabiedrībā ar ārstu, aprūpes vai pedagogiskā personāla konstruēto diskursu starpniecību.

Eiropas ārsti 19. gadsimtā apzināja dažādas garīgās attīstības traucējumu pakāpes un tās cēloṇus, kā arī izstrādāja pamatus veselības aprūpes un pedagoǵijas sistēmām. Pakāpeniski tika izveidotas atsevišķas nodaļas psihiatriskajās slimnīcās vai atsevišķas iestādes ar mērķi uzsākt pedagoǵiski medicīnisku praksi, kas būtu pielāgota bērniem ar garīgās attīstības traucējumiem. Kā piemēru šadai praksei var minēt tādus franču ārstus kā Gijoms Ferro (Guillaume Marie-André Ferrus, 1784-1861), kas 1828. gadā atvēra idiotijas ārstēšanai paredzētu nodaḷu Bisetras Psihiatriskajā dziednīcā, Žans Pjērs Falrē (Jean-Pierre Falret, 1794-1870), kas 1831. gadā tādu pašu nodaḷu atvēra Salpetjēras slimnīcā (Pitié-Salpêtrière

1 Patrick McDonagh, C. F. Goodey, \& Tim Stainton, "Introduction: the emergent critical history of intellectual disability" in Intellectual Disability: A Conceptual History, 1200-1900, ed. Patrick McDonagh, C. F. Goodey, \& Tim Stainton (Manchester: Manchester University Press, 2018), 1. 
Hospital)², un Fēlikss Vuazēns (Félix Voisin, 1794-1872), kas 1834. gadā Parīzē, Is̄̄-le-Mulino (Issy-les-Moulineaux), nodibināja patstāvīgu iestādi ar pielāgotu izglītību un mācību metodēm garīgo spēju un intelekta attīstībai, diemžēl ar īslaicīgu darbību, - Ortofrēnijas skolu (l'Ecole orthophrénique). ${ }^{3}$

1838. gadā Johans Gugenbūls (Johann Jakob Guggenbühl, 1816-1863) Abenbergā Šveicē atvēra un vadīja klīniku, kurā rūpējās par bērniem, kam bija noteikta kretīnisma diagnoze vai arī garīgi un fiziski traucējumi. ${ }^{4}$ 1839. gadā Eduards Segēns (Édouard Séguin, 1812-1880) Parīzē nodibināja pasaulē pirmo skolu bērniem ar garīgiem traucējumiem. ${ }^{5}$ Tā ieguva starptautisku atpaz̄istamību un veicināja līdzīgu institūciju veidošanos citur Eiropā un ASV. 1848. gadā Hervejs B. Vilbūrs (Hervey B. Wilbur, 1820-1886) ASV nodibināja privātu internātskolu bērniem ar garīgās attīstības traucējumiem, un divus gadus vēlāk Samuels Gridlejs Hovs (Samuel Gridley Howe, 1801-1876) Masačūsetsā - skolu jauniešiem, kas cieta no idiotijas un garīgās attīstības traucējumiem; tā bija pirmā valsts internātskola ASV. ${ }^{6}$ Vācijā ap 19. gadsimta vidu (nedaudz pirms) mainījās skatījums uz tādu bērnu, kuriem ir garīgās attīstības traucējumi, izglītošanu. To vairs neuztvēra kā jaunu pedagoǵijas nozari, bet gan kā speciālu medicīniski ārstniecisku pedagoǵiju (Heilpädagogik). 1861. gadā Vīnes tuvumā divi austriešu ārsti - Jans Daniels Georgens (Jan-Daniel Georgens, 1823-1886) un Heinrihs M. Deinhards (Heinrich Marianus Deinhardt,

2 Hananijs Zamskis, Speciālās pedagoǵijas vēsture: Bērnu ar garīgās attīstības traucējumiem izpētes, audzināšanas un mācī̌sanas vēsture no senajiem laikiem lìdz 20. gadsimta vidum, saīsināts tulkojums ([Rīga]: RaKa, 2007), 29.

3 University Hospital Group Paris: Psychiatrie \& Neuroscience, Histoire de la pédopsychiatrie en France: De Pinel à Heuyer: 1809-1937, Bibliothèques \& Documentation (Paris: Bibliothèque médicale Henri Ey, 2017), 8, 3.

4 Christian Müller, "Johann Jakob Guggenbühl” in Die Schweizischen Akademie der Geistes- und Sozialwissenschaften, Historische Lexikon der Schweiz (HLS), März 20, 2007, abgerufen Oktober 9, 2019, https://hls-dhs-dss.ch/de/ articles/014393/2007-03-20/.

5 The Editors of Encyclopaedia Britannica, "Edouard Séguin," Encyclopædia Britannica, Encyclopcedia Britannica, inc., published October 24, 2019, accessed December 9, 2019, https://www.britannica.com/biography/Edouard-Seguin.

6 "The Establishment of Schools for the Disabled," Science and Its Times: Understanding the Social Significance of Scientific Discovery, Encyclopedia.com, accessed December 9, 2019, https:/www.encyclopedia.com/science/encyclopedias-almanacstranscripts-and-maps/establishment-schools-disabled. 
1821-1880) - dibināja medicīnisku un izglītojošu iestādi Heilpflege- und Erziehungsanstalt "Levana” un šo terminu izmantoja kā apzīmējumu atseviškai zinātnes nozarei. ${ }^{7}$

Jautājumi par sociālo aprūpi tika aktualizēti arī Krievijas Impērijā jau 18. gadsimta otrajā pusē. 1775. gadā ķeizariene Katrīna II Lielā izdeva likumu, kas Vidzemes guberṇā stājās spēkā 1783. gadā un kurā tika noteikts, ka guberṇās jānodibina Sabiedriskās aizgādības kolẹgijas, kuru uzdevums ir rūpēties par slimiem un trūcīgiem iedzīvotājiem, kā arī izveidot dziedniecības iestādes. ${ }^{8}$ Neskatoties uz to, Latvijas teritorijāa, kas bija Krievijas Impērijas sastāvā, līdz 19. gadsimta vidum nebija izveidotas speciālās izglītības vai aprūpes iestādes cilvēkiem ar garīgās attīstības traucējumiem. Militārajās ǵimnāzijās bija pagarināts mācību ilgums bērniem, kuru attīstība aizkavējās, un mācības vēlāk varēja turpināt militārās proǵimnāzijās, bet tās nevar uzskatīt par palīgskolām ar speciālu apmācību. ${ }^{9}$ Lìdzīgi kā Rietumeiropā, 19. gadsimtā arī Krievijas Impērijā atvēra tikai atsevišķas privātas patversmes, skolas vai klases, kurās uzraudzīja un izglītoja bērnus ar garīgās attīstības traucējumiem. ${ }^{10}$

\section{Speciālās izglītības un garīgās veselības aprūpes aizsākums Latvijas teritorijā}

Latvijā situācija main̄̄jās 1854. gadā, kad Rīgā nodibināja pirmo iestādi bērniem, kam diagnosticēta epilepsija un garīgās attīstības traucējumi. ${ }^{11}$ To izveidoja Frīdrihs Placs (Friedrich Platz, 1823-1864), kurš bija ieguvis medicīnisko un pedagoǵisko izglītību. ${ }^{12}$ Kēnigsbergā viṇš tika

7 Willian O. McCagg, "The Origins of Defectology", in The Disabled in the Soviet Union: Past and Present, Theory and Practice, Series in Russian and East European Studies; no. 12, ed. William O. McCagg \& Lewis Siegelbaum, "Conference from which this book emerges was held at Michigan State University on 11-13 April 1985" (Pittsburgh: University of Pittsburgh Press, 1989), 46.

${ }^{8}$ Hermanis Buduls, Latvijas galvas pilsētas Rīgas Sarkankalna slimnīcas vēsture, 1862.-1937. ([Rīga]: Pilsētas valde, 1938), 5.

9 Hananijs Zamskis, Speciālās pedagogijas vēsture (Rīga: RaKa, 2007), 214.

10 Jāzeps Kravalis, Latvijas speciālās skolas (1840-1996) (R̄̄ga: Mācību grāmata, 1997), 15.

11 Jahresbericht über die Leistungen und Fortschritte auf dem Gebiete der Neurologie und Psychiatrie, V. Jahrgang (Berlin: S. Karger, 1902), 1027.

12 Die heilpädagogische Anstalt der Frau Th. W. Platz in Riga (Riga: Druck von W. F. Häcker, 1896), 3. 
apmācīts par kurlmēmo skolotāju. ${ }^{13}$ Rīgā atvērt mācību iestādi viṇu pamudināja nedzirdīgo un kurlmēmo skolotājs Karls Vilhelms Zēgerts (Karl Wilhelm Saegert, 1809-1879), ${ }^{14}$ kas bijis direktors Karaliskajā nedzirdīgo iestādē (Königlichen Taubstummenanstalt) Berlīnē un Vācijas imperatora Frīdriha III Hoencollerna (Friedrich III; 1831-1888) privātskolotājs. ${ }^{15}$ Frīdrihs Placs tika iecelts par skolotāju Rīgas Literāri praktiskās pilsoṇu savienības kurlmēmo skolā (Taubstummenschule der literärisch-praktischen Bürgerverbindung), kurā strādāja kopš 1847. gada. ${ }^{16}$ Viņš kopā ar savu dzīvesbiedri Terēzi Placu (Therese Platz, dzim. Gērkena-Fērmane (Geerken-Fehrmann)) to vēlāk paplašināja. ${ }^{17}$

Kaut gan Frīdrihs Placs bija atbraucis Rīgā strādāt par kurlmēmo skolotāju, viṇš izveidoja iestādi cilvēkiem ar garīgās attīstības traucējumiem, ${ }^{18}$ jo skolā bija uzṇemti arī tie, kam diagnosticēta idiotija. Frīdrihs Placs no Tērbatas mācību apgabala kuratora un Rīgas pilsētas Medicīnas pārvaldes saṇēma atļauju dibināt iestādi, un koncesija uzticēja iekārtot šo iestādi piecpadsmit idiotijas pacientiem. ${ }^{19}$ 1854. gadā iestāde tika atklāta un savu darbību sāka ar četriem audzēkņiem, no kuriem viens bija divdesmitgadīgs un cieta no idiotijas un epilepsijas, savukārt trīs audzēkṇi bija ar garīgās attīstības traucējumiem. ${ }^{20}$ Iestādē uzṇēma ne tikai bērnus ar diagnosticētu idiotiju, bet arī tādus, kam bija diagnosticēta epilepsija, kā arī audzēkṇus ar dzirdes un dažādu pakāpju garīgās attīstības traucējumiem.

13 Die heilpädagogische Anstalt der Frau Th. W. Platz in Riga (Riga: Druck von W. F. Häcker, 1896), 3.

14 Dagmar Hänsel und Hans-Joachim Schwager, Die Sonderschule als Armenschule: vom gemeinsamen Unterricht zur Sondererziehung nach Braunschweiger Muster, Explorationen, Studien zur Erziehungswissenschaft, 43 (Bern: Peter Lang, 2004), 157.

15 "Carl W. Saegert (1809-1879)," Catalogue général de la Bibliothèque nationale de France, création: Mars 17 2014, https://catalogue.bnf.fr/ark:/12148/cb17113933p.

16 Die heilpädagogische Anstalt der Frau Th. W. Platz in Riga, (Riga: Druck von W. F. Häcker, 1896), 3.

17 Heinrich Laehr und Max Lewald, Die Heil- und Pflege-Anstalten für PsychischKranke des deutschen Sprachgebietes am 1. Januar 1898 (Berlin: Verlag von Georg Reimer, 1899), XI, 235.

18 "Die Platz'sche heilpädagogische Anstalt in Sassenhof," Düna Zeitung, nr. 178 (August 10, 1894): 1.

19 Jāzeps Kravalis, Latvijas speciālās skolas (1840-1996) (Rīga: Mācību grāmata, 1997), 15.

20 Die heilpädagogische Anstalt der Frau Th. W. Platz in Riga (Riga: Druck von W. F. Häcker, 1896), 4. 
Frīdrihs Placs bija iestādes direktors un pildīja arī skolotāja pienākumus. Iestādē tika apvienota ārstēšana un izglītošana. Ārstēšanas process bija balstīts uz psiholoǵisku, pedagoǵisku un medicīnisku aprūpi, un šādai ārstnieciskai izglītībai bija nepieciešama rūpīga katra skolēna garīgā stāvokḷa izpēte. ${ }^{21}$

Iestādes pastāvēšanas laikā tai vairākas reizes ir mainīts nosaukums. Kādu laiku tā tika dēvēta par kurlmēmo mācību iestādi (Taubstummenbildungs-Anstalt). ${ }^{22}$ Kaut gan tā bija ārstnieciski pedagoǵiska iestāde, to sauca arī par patversmi, ko vēlāk paplašināja, un tā pildīja arī pansionāta funkcijas. 1863. gadā iestāde saṇēma ārstnieciski izglītojošas pansijas (heilpädagogischen Pension) nosaukumu, tāpēc tajā idiotijas pacientus atdalīja no bērniem ar dzirdes traucējumiem un paplašināja mācību programmu, lai pielāgotu dažādām garīgās attīstības traucējumu pakāpēm, kam vēsturiski lietoti apzīmējumi 'idioti' (Idioten), 'garīgi atpalikušie' (geistig zurückgebliebene) un 'nenormālie' (abnorme). ${ }^{23}$ Neilgi pēc šo pacientu atdalīšanas iestāde ieguva citu nosaukumu - kurlmēmo skola un iestāde idiotiem (Taubstummen-Schule und Idioten-Anstalt). ${ }^{24}$ Pēc tam tai bijuši vēl vairāki nosaukumi: Idioten-Anstalt, ${ }^{25}$ Idioten und heilpädagogischen Anstalt, ${ }^{26}$ Heilanstalt für Schwachsinnige und Epileptiker. ${ }^{27}$

Desmit gadus pēc iestādes dibināšanas, 1864. gada aprīlī, Frīdrihs Placs nomira, un pēc tam par oficiālo tās vadītāju un īpašnieci kḷuva viņa atraitne Terēze Placa, kas līdz tam šajā iestādē bija strādājusi kopā ar savu vīru. ${ }^{28}$

21 Kurze Mittheilungen für das Jahr 1887 über das Wesen und den Bestand der Heilpädagogischen Anstalt der Frau Therese Platz. Riga, Sassenhof 3. Station der Tuckumer Bahn, Goldingerstraße Nr. 35. Privat-Anstalt für geistig Zurückgebliebene, Krampfleidende und Schwaschsinnige, gegründet 1854 von dem weil. TaubstummenLehrer Friedrich Platz, seit 23 Jahren fortgesetzt von seiner Wittwe Therese Platz (Riga: Druck von W. F. Häcker, 1888), 6.

22 Rigasches Adreß-Buch für 1861 (Riga: Verlag von N. Kymmel, [1861]), 61.

23 “Die Platz'sche heilpädagogische Anstalt in Sassenhof," Düna Zeitung, nr. 178 (August 10, 1894): 1.

24 Rigasches Adreß-Buch für 1864/65: Mit einem Plane der Stadt (Riga: Verlag von N. Kymmel, [1864]), 120.

25 Rigasches Adreß-Buch für 1868/69 (Riga: Verlag von N. Kymmel, 1868).

26 Rigasches Adreß-Buch für 1877 (Riga: Verlag von N. Kymmel, 1877), 148.

27 Rigasches Adreßbuch 1902, herausgegeben von Adolf Richter (Riga: Im Selbstverlage des Herausgebers, [1902]), 572.

28 Die heilpädagogische Anstalt der Frau Th. W. Platz in Riga, (Riga: Druck von W. F. Häcker, 1896), 3. 
Viṇa piekrita vadīt iestādi pēc atkārtotiem labdarības organizāciju lūgumiem. ${ }^{29}$

Iestāde darbu bija sākusi 1854. gadā Rīgas kurlmēmo bērnu skolas telpās. ${ }^{30}$ Tās atrašanās vieta Aleksandra ielā 38 (Alexanderstraße, pašlaik: Brīvības iela), dzīvīgā pilsētas vidē ar nelielu dārzu, kas bija tās rīcībā, neatbilda šādas iestādes vajadzībām. ${ }^{31}$ 1870. gadā to pārcēla uz Nikolaja ielu 55 (Nicolaistraße, pašlaik Krišjāṇa Valdemāra iela), kur ēkai bija lielāka platība un tās apkārtnē bija dārzs un plava. ${ }^{32}$ Taču arī šīs telpas nebija piemērotas, tādēl Terēze Placa turpināja meklēt iestādei atbilstošu vietu un telpas. 1879. gadā viṇa par saņemto hipotekāro aizdevumu iegādājās jaunu īpašumu ${ }^{33}$, un iestāde uzsāka darbību Zasumuižā (Sassenhof) Rīgā, Kuldīgas ielā 35 (Goldingenstraße, tagadējā Zasulauka apkaimē Pārdaugavā, Latvijas Universitātes Botāniskā dārza tuvumā). ${ }^{34}$ Radās nepieciešamība pārbūvēt iestādes ēku, jo tā sakarā ar aprūpējamo skaita palielināšanos bija kḷuvusi par mazu iestādes vajadzībām. Direktore pieņēma lēmumu pārveidot ēkas kompleksu, padarot to ērtāku aprūpējamo izmitināšanai. Pēc hipotekārā kredīta aizdevuma iegūšanas ēka tika pārbūvēta un paplašināta, un 1887. gadā tai pievienoja vēl vienu korpusu. ${ }^{35}$ Tās renovācija tika pabeigta 1887. gada vasarā. ${ }^{36}$ Ēkā paplašināja virtuves un saimniecības telpas un izveidoja arī īpašu vannasistabu. ${ }^{37}$

29 Jāzeps Kravalis, Latvijas speciālās skolas (1840-1996) (Rīga:RaKa, 1997), 16.

30 Ibid, 15-16.

31 Die heilpädagogische Anstalt der Frau Th. W. Platz in Riga (Riga: Druck von W. F. Häcker, 1896), 4.

32 Ibid.

33 Ibid.

34 Heinrich Laehr und Max Lewald, Die Heil- und Pflege-Anstalten für PsychischKranke des deutschen Sprachgebietes am 1. Januar 1898, 235.

35 Die heilpädagogische Anstalt der Frau Th. W. Platz in Riga (Riga: Druck von W. F. Häcker, 1896), 4.

36 Kurze Mittheilungen für das Jahr 1887 über das Wesen und den Bestand der Heilpädagogischen Anstalt der Frau Therese Platz. Riga, Sassenhof 3. Station der Tuckumer Bahn, Goldingerstraße Nr. 35. Privat-Anstalt für geistig Zurückgebliebene, Krampfleidende und Schwaschsinnige, gegründet 1854 von dem weil. TaubstummenLehrer Friedrich Platz, seit 23 Jahren fortgesetzt von seiner Wittwe Therese Platz, 6.

37 A. Schwartz und G. Poelchau, "Literärisch-praktische Bürgerverbindung. Jahresbericht der Delegirten der lit.-praktischen Bürgerverbindung bei der heilpädagogische Anstalt der Frau Therese Platz für 1882/83," Rigasche Stadtblätter, nr. 22 (Juni 2, 1883): 157-158. 
Paplašināšanas darbi tika veikti kopumā divas reizes. ${ }^{38}$

Sabiedrība novērtēja Terēzes Placas ieguldījumu. Iestādes vadītāju apbalvoja ar sudraba medaļu un piešķīra goda diplomu. ${ }^{39}$ Arī laikrakstos viņai tika veltīta atzinība: "Pašā Rīgā kāda kristīga atraitne savā privātiestādē tādus nelaimīgus kopj jau ilgāk par 30 gadiem, bet tas tik ir mazs pulciņš, ko tā spēj uzṇemt pie sevis", norādot, ka Vidzemē un Tērbatā bērni, kurus vajadzētu uzṇemt šāda veida iestādēs, dzīvo neatbilstošos apstākḷos ${ }^{40}$ Vēl 19. gadsimta beigās šāda tipa iestādes bija retums. Līdz 1881. gadam tā bija vienīgā specializētā mācību iestāde Krievijas Impērijā, ${ }^{41}$ kaut gan nepieciešamība pēc šādām iestādēm cilvēkiem ar garīgās attīstības traucējumiem bija liela, jo to skaits bija liels. 1882. gadā tāda tipa iestāde tika dibināta Pēterburgā, ${ }^{42}$ bet ar to arī nebija pietiekami, lai visiem nodrošinātu uzṇemšanu. Terēzes Placas iestāde joprojām bija vienīgā šāda veida iestāde līdzās tikai dažām - Imanuēla Stifta (Immanuel Stift) iestādei Pēterburgā un iestādei "Tabors" "epileptiķiem un dumjajiem" (Anstalt “Tabor” für Epileptische und Blöde) Jelgavā. ${ }^{43}$

Pēc Frīdriha Placa nāves Terēze Placa turpināja vīra iesākto darbu un pansionātu vadīja līdz pat savai nāvei. Pēc tam iestādes vadību pārṇēma ārsts Aleksandrs Fērmanis (Alexander Fehrmann). Iestādei par godu tās ilggadējai vadītājai Terēzei Placai ${ }^{44}$ piešķīra nosaukumu Heilanstalt "Theresia" für Schwachsinnige und Epileptiker ${ }^{45}$ (Ārstniecības iestāde “Theresia” plānprātīgiem un epileptiķiem), vēlāk arī Heil und Pflegeanstalt “Theresia” Ārstniecības un aprūpes iestāde “Theresia”). Iestāde pastāvēja

38 “Die Platz'sche heilpädagogische Anstalt in Sassenhof," Düna Zeitung nr. 178 (August 10, 1894): 1.

39 Heinrich Laehr und Max Lewald, Die Heil- und Pflege-Anstalten für PsychischKranke des deutschen Sprachgebietes am 1. Januar 1898, 235.

40 “Uzaicinājums," Mājas Viesis, nr. 39 (21. septembris 1894): 7.

41 Heinrich Laehr und Max Lewald, Die Heil- und Pflege-Anstalten für PsychischKranke des deutschen Sprachgebietes am 1. Januar 1898, 235.

42 Jahhresbericht über die Leistungen und Fortschritte auf dem Gebiete der Neurologie und Psychiatrie, V. Jahrgang (Berlin: S. Karger, 1902), 1027.

43 “Die Platz'sche heilpädagogische Anstalt in Sassenhof," Düna Zeitung, nr. 178 (August 10, 1894): 1.

44 Rigasches Adreßbuch 1906, herausgegeben von Adolf Richter (Riga: Im Selbstverlage des Herausgebers, [1906]), 508.

45 Rigasches Adreßbuch 1903, herausgegeben von Adolf Richter (Riga: Im Selbstverlage des Herausgebers, [1903]), 484. 
līdz Pirmajam pasaules karam, bet pēc tam pārgāja Sociālās nodrošināšanas ministrijas pārzin̄ā un darbojās līdz Otrajam pasaules karam (1941. gadam). ${ }^{46}$

\section{Garīgās nespējas reprezentācija sabiedrībā}

Deviņpadsmitajā gadsimtā medicīnas un pedagoǵijas nozares, valsts pārvaldes, reliǵisko un labdarības organizāciju pārstāvji un sabiedrība kopumā izrādīja interesi par cilvēkiem ar garīgās attīstības traucējumiem kā neaizsargātu sociālu grupu. Informācija par personām ar garīgās attīstības un citiem veselības traucējumiem tika pausta informatīvajā telpā ar dažādu publikāciju starpniecību. To vidū bija ne tikai grāmatas vai publikācijas preses izdevumos ar zinātnisku saturu, bet arī institucionāli izdevumi, kuros sniegti darbības pārskati un izklāsti par iestādēs uzṇemtajiem. Rezultātā šiem cilvēkiem tika pievērsta gan uzraudzības iestādes, gan arī sabiedrības uzmanība. Tā kā iestāde saṇēma darbības ațauju un finansiālu atbalstu, tās vadība sniedza pārskata ziņojumus par savu darbību, savukārt varas institūciju pārstāvji un interesenti varēja sekot līdzi iestādes darbībai.

Frīdriha Placa dibinātā iestāde darbības sākumā tika pārvaldīta, izmantojot Placa paša finansiālos līdzekḷus. 1883. gadā tā kḷuva par maksas iestādi. ${ }^{47}$ Tomēr vēlāk tā uzṇēma arī trūcīgus bērnus, no kuriem naudu neiekasēja, tādēḷ tai bija nepieciešams saṇemt finansiālu atbalstu. Iestāde saṇēma ziedojumus no pilsētas pārvaldes, Rīgas Literāri praktiskās pilsoṇu savienības, Pilsētas nabagu nama, labdarības iestādēm un privātpersonām - Rīgas iedzīvotājiem. ${ }^{48}$ Pārējo ienākumu avots bija maksājumi par aprūpējamo un apmācāmo uzturēšanos iestādē, ko sedza viṇu vecāki, aizbildņi vai ziedotāji. Iestādes publikācijas bija kā atskaites ne tikai par saṇemto finansējumu, bet arī par darbības kvalitāti un efektivitāti: Terēze Placa iestādes darbības ziņojumos sniedza informāciju arī par iestādes dienas kārtību, mācību metodēm un saturu, darbā iesaistīto personālu un tās audzēkn,iem.

46 Jāzeps Kravalis, Latvijas speciālās skolas (1840-1996) (Rīga: RaKa, 1997), 18.

47 Heinrich Laehr und Max Lewald, Die Heil- und Pflege-Anstalten für PsychischKranke des deutschen Sprachgebietes am 1. Januar 1898, 235.

48 Die heilpädagogische Anstalt der Frau Th. W. Platz in Riga (Riga: Druck von W. F. Häcker, 1896), 3-4. 
Iepriekš minētajiem iestādes ziṇojumiem līdzīga satura informācija ir atrodama Frīdriha Placa fotogrāfiju albumā ar nosaukumu "Idioten-Anstalt", kas tika drukāts 1862. gadā Rīgā, Ernsta Arnolda Plātesa grāmatu spiestuvē (Ernst Plates Stein- und Buchdruckerei), un izdots ar cenzūras atḷauju. Šajā sakarā jāpiemin, ka starptautiskā kontekstā līdz ar t.s. medicīniskās fotogrāfijas ieviešanu aizvien izplatītākas kḷuva ar fotogrāfijām papildinātas medicīniska satura publikācijas un dokumentācija. Fotogrāfija kḷuva par nozīmīgu daḷu līdzās tekstuālajai informācijai, pateicoties tās spējai fiksēt redzamo un drošticamībai. Attēls bija pierādījums un noderēja "patiesības reǵistram". ${ }^{49}$ Fotogrāfijas pildīja administratīvu funkciju, tāpēc tās tika ieviestas valsts psihiatriskajās institūcijās, patversmēs un arī valdības institūcijās, ${ }^{50}$ kuru vidū var ierindot ar̄̄ Frīdriha un Terēzes Placu iestādi. Šādu dokumentāciju mēdza papildināt ar portretiem personu identifikācijai. Kristians Felins (Christian Phéline) grāmatā L'image accusatrice skaidro, ka fotogrāfiju kā sociālās kontroles instrumentu lietoja tādās nozarēs kā psihiatrija un tiesu vara, kur tā tika izmantota personas identifikācijai, kad parādījās cartes-de-visite fotogrāfijas. ${ }^{51}$ Ar̄̄ Frīdriha Placa iestādes albumā ir cartes-de-visite fotogrāfijas, kas līdzās tekstuāli reǵistrētajiem datiem par personām bija kā papildu avots ar vizuālu atspoguḷojumu portretos, kas sniedza pilnīgāku un ticamu informāciju.

Atsaucoties uz Deivida Arnolda (David Arnold) viedokli, iestādēs uzṇemto personu fotografēšana ir uzskatāma par daḷu no institucionālās uzraudzības un kontroles. ${ }^{52}$ To var pamatot ar fotogrāfijas spēju fiksēt redzamo, kas bija iekḷauts institucionālajā dokumetācijā kā pierādījums. Džons Tags (John Tagg) uzskata, ka pastāvīgā institucionālā uzraudzība radīja jaunas zināšanas par subjektiem un varu, kas bija saglabāta, pateicoties izplatītajai informācijai, kurā fotogrāfija bija daḷa no tās. ${ }^{53}$

49 John Tagg, "Evidence, truth and order: a means of surveillance: photographic records and the growth of the state," in Visual Culture: The Reader, J. Evans, \& S. Hall, ed. (London: SAGE Publications, 1999), 246.

50 Andreas Broeckmann, "A Visual Economy of Individuals: The Use of Portrait Photography in the Nineteenth-Century Human Sciences" (revised version of the PhD thesis, University of East Anglia, 1995), 97.

51 Christian Phéline, L'image accusatrice (Laplume: Association de critique contemporaine en photographie, 1985).

52 David Arnold, "In Search of the Colonial Subject," in Clio/anthropos: exploring the boundaries between history and anthropology, A. Willford, \& E. Tagliacozzo, ed. (Stanford, Calif.: Stanford University Press, 2009), 43.

53 John Tagg, "Evidence, truth and order," in Visual Culture: The Reader, J. Evans, \& S. Hall, ed. (London: SAGE Publications, 1999), 245. 


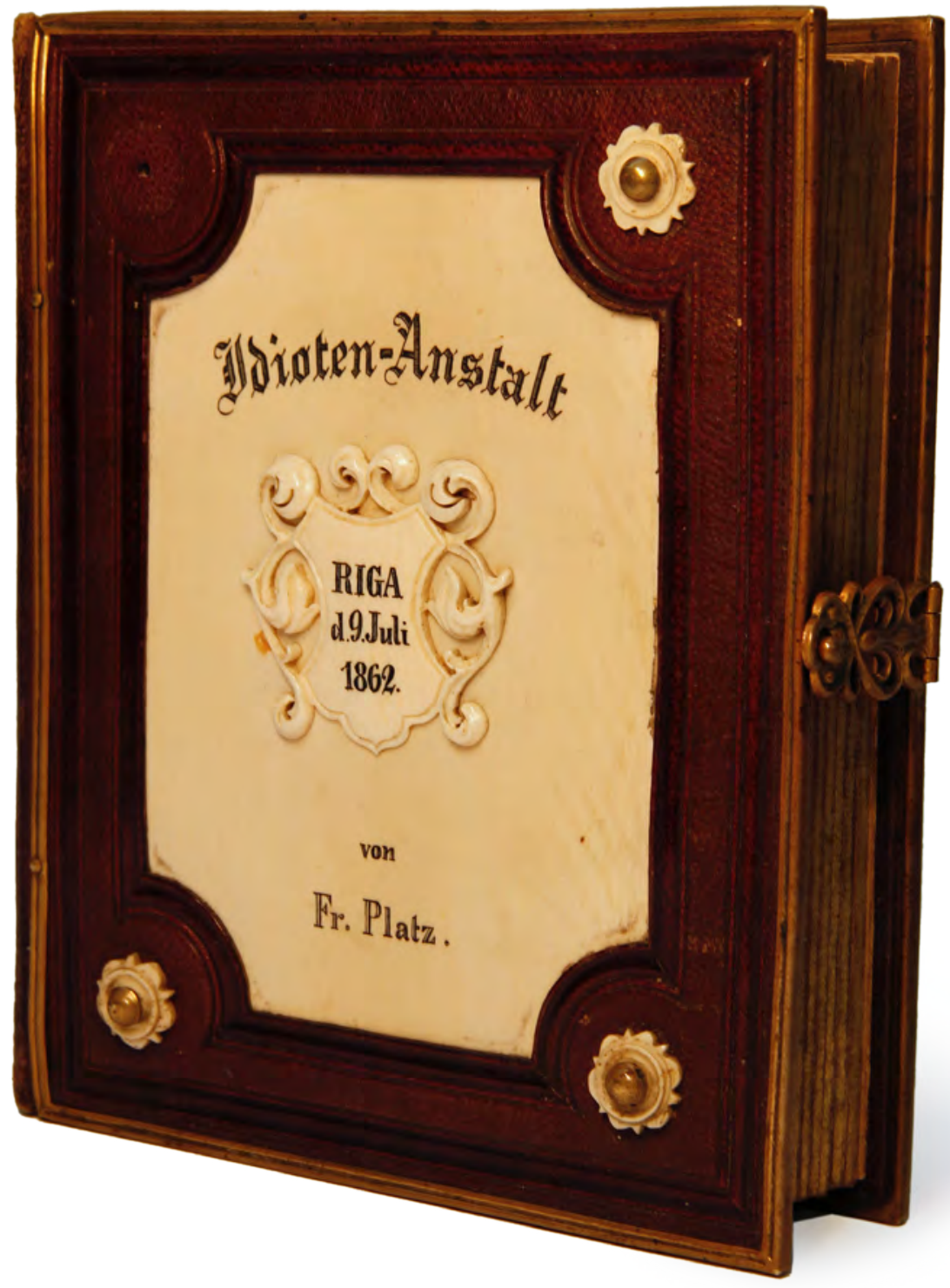

Albums "Idioten-Anstalt von Fr. Platz: Riga d. 9. Juli 1862"

(Rīga: Ernst Plates Stein- und Buchdruckerei; no Latvijas Nacionālās bibliotēkas Reto grāmatu un rokrakstu krājuma) 
Tas bija novērojams reizēs, kad ārsts vai skolotājs tekstuāli un fotogrāfiski fiksēja savas metodes un novērojumus par institūcijā uzṇemtajiem un pēc tam izplatîja dažādos informācijas avotos, tādā veidā nostiprinot savu statusu un kompetenci, vienlaikus reprezentējot institūcijā uzṇemtās personas.

Iestādes fotogrāfiju albums pildīja reǵistra funkciju administratīvām vajadzībām. Var uzskatīt, ka iestādes toreizējais vadītājs Frīdrihs Placs pieṇēma lēmumu par audzēkṇu fotogrāfiju albuma izgatavošanu, kurā būtu apkopota slimības vēsturei līdzīga informācija par iestādes audzēkņiem un to fotogrāfijas, tādēl pieaicināja profesionālus baltvācu un vācu fotogrāfus, kas izgatavoja divdesmit piecu portretu sēriju, ko ietvēra albuma otrajā daḷā. Analizējot albuma fotogrāfijas, ir būtiski vērst uzmanību uz reprezentācijas pieeju, kas atkarībā no to radīšanas nolūka un no tā izrietošiem stilistiskiem risinājumiem noteica vizuālo retoriku. Albuma fotogrāfiju stilistiskais risinājums bija atkarīgs no albuma autora ieceres un fotogrāfa izpratnes par fotogrāfiju izmantošanas ieceri, kā arī no fotogrāfa profesionālā veikuma, jo portretu sērija bija pasūtījuma darbs. Identitātes reprezentācija fotogrāfijā mēdza būt atškirīiga - fotogrāfija varēja paust portretējamā priekšstatu par sevi vai arī to, kā portretējamo personu redz citi. Pirmajā variantā fotogrāfija pilda pašreprezentatīvu funkciju (savas personības paušanu, kas balstīta uz priekšstatu par sevi jeb pašizjūtu), bet otrajā - uzraudzības jeb, citiem vārdiem sakot, identitātes kontroles funkciju. No vienas puses, atbilstoši minētajam otrajam variantam fotogrāfijas pēc iekḷaušanas albumā kḷuva par daḷu no institucionālās dokumentācijas, un audzēkņi tādā veidā bija identificējami ne tikai pēc vārda un uzvārda, bet arī pēc izskata, kā arī tika reǵistrēti kā iestādē uzņemtie subjekti. No otras puses, portretu stilistiskie risinājumi atbilda konkrētā laika portretu fotogrāfijas estētiskajām konvencijām un pieņemtajiem standartiem par studijas iekārtojumu un portretējamo cilvēku pozām. Albuma fotogrāfijas bija reprezentācijas forma ar vēsturiski specifisku rāmējumu: no vienas puses, tās atspoguloja iestādes audzēkṇus institucionālā kontekstā, no otras - vizuāli neatšķ̄īās no ierastajiem un plaši izplatītajiem 19. gadsimta komerciālajiem portretiem.

Fotogrāfijas derēja par pierādījumu institucionālās darbības efektivitātei, jo kopumā veiksmīgi uzņemtajos portretos vizuālā retorika ar studiju dekorāciju, svinīga apgeērba un pozu palīdzību skatītāja uztverē radīja ilūziju par labvēlīgiem apstākḷiem un priekšzīmīgām manierēm attiecīgajā iestādē. 

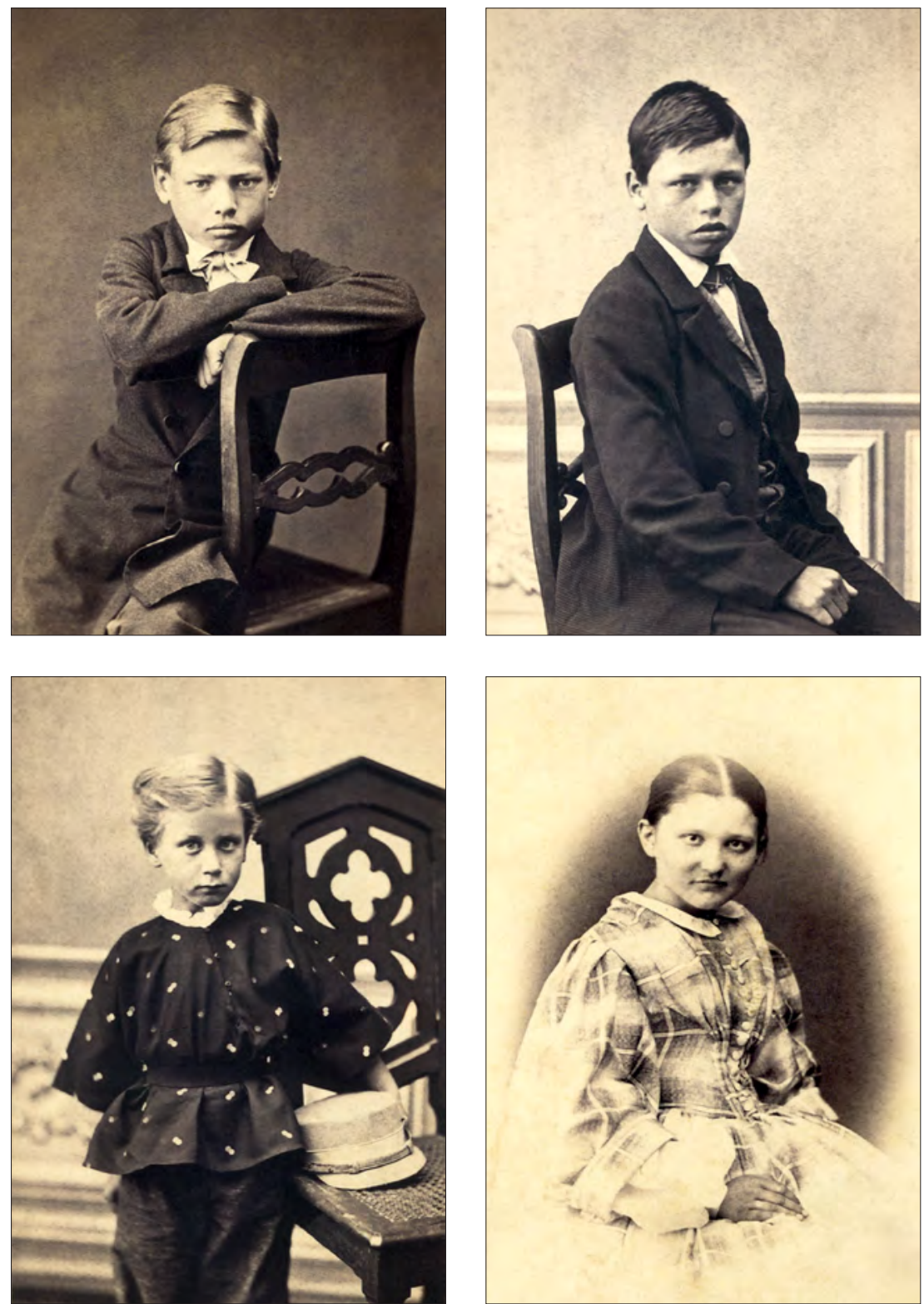

Karla fon Lindes (Carl von Linde) fotogrāfijas no albuma

"Idioten-Anstalt von Fr. Platz: Riga d. 9. Juli 1862", 19. gs. 60. gadi (no Latvijas Nacionālās bibliotēkas Reto grāmatu un rokrakstu krājuma) 
Placa iestādes albuma tekstuālajā sākumdaḷā Notizen zum Album katra audzēkņa raksturojums kārtots numurētā sarakstā un otrajā daḷā ir pievienotas audzēkṇu fotogrāfijas,. Iestādes vadība nodrošināja informācijas uzskaiti par aprūpējamajiem, kas kalpoja kā administratīvs mehānisms, fiksējot viņu biogrāfiskos datus un dokumentējot uzvedību, paradumus, ikdienas gaitas, īpaš̄̄bas, papildinot šos personu raksturojumus ar noteiktām diagnozēm. Ar šajā albumā izmantotajiem diskursiem tika veidots priekšstats par garīgo nespēju. Albums kā kontroles instruments bija veidots ar mērḳi dokumentāri reǵistrēt un klasificēt tos, kas nonākuši iestādes aprūpē, novērtēt viṇu progresu apmācību procesa gaitā un salīdzinot viņu uzvedību un spējas fotogrāfju uzṇemšanas laikā un vēlāk. Publicētā informācija kalpoja kā pamatojums iestādes efektivitātei, norādot audzēkṇu intelektuālo spēju, veselības stāvokḷa un uzvedības izmaiņas, pretstatot personu kādreizējo stāvokli un uzlabojumus, kas sasniegti pēc uzturēšanās iestādē. Kā piemēri minami veselības stāvokḷa un intelektuālo spēju uzlabošanās, sekmes mācībās, patstāvība, priekšzīmīga uzvedība. Kaut arī diagnozes minētajos gadījumos palika nemainīgas, tika novērots, ka personu spējas un uzvedība uzlabojās, kas minēts albumā, tā norādot uz tuvošanos pieņemtajām normām. Diskursi par subjektiem ietvēra raksturojumus, kas pauda to neatbilstību sociāli pieņemtajām intelektuālajām spējām un uzvedības normām. Šie raksturojumi bija kā pamatojumus, no kā izrietēja subjektu definējums atbilstoši konkrētā laika diagnožu klasifikācijai. Iestādes albumā norādītas tādas attiecīgā laika terminoloǵijā lietotās diagnozes kā 'idiots' (idiot) un 'plānprātīgs' (schwachsinnig) vai norāde, ka audzēknis ir kurlmēms (taubstumm), ${ }^{54}$ savukārt 1896. gadā Terēzes Placas sagatavotajā ziṇojumā ir aprakstītas garīgajām spējām pielāgotas mācību metodes, kas bija noteiktas atbilstoši tā laika terminoloǵiskajai diagnožu klasifikācijai:

1. grupa - 'neapdāvinātie' (Schwachbegabten) skolēni;

2. grupa - 'jaunākie neapdāvinātie' (jüngeren unreisen Schwachbegabten) un 'attīstītāki neapdāvinātie' (entwickelteren Schwachbegabten);

3. grupa - 'plānprātīgie' (Schwachsinnigen) un 'dumjie' (Blödsinnigen), kas nav nodarbināti; 4. grupa - 'idioti' (Idioten) un 'pilnīgi idioti' (Voll-Idioten). ${ }^{55}$

54 Friedrich Platz, Idioten-Anstalt von Fr. Platz: Riga d. 9. Juli 1862 (Riga: Ernst Plates Stein- und Buchdruckerei, 1862), RIL-1/247, Latvijas Nacionālās bibliotēkas Reto grāmatu un rokrakstu krājums. 1-8.

55 Die heilpädagogische Anstalt der Frau Th. W. Platz in Riga (Riga: Druck von W. F. Häcker, 1896), 6-7. 
Albuma un ziņojumu satura medicīniskajos diskursos bija pausts sociālo grupu iedalījums atbilstoši tolaik pieņemtās garīgās nespējas diagnožu klasifikācijai. Iestāde nodrošināja kompetentu speciālistu pakalpojumus, kas personu novērojumu rezultātā noteica diagnozes un nonāca pie slēdzieniem par nepieciešamo apmācību un aprūpes veidu. Personu identitāte bija atkarīga no speciālajām institūcijām, kuras noteica diagnozi. ${ }^{56}$

Institucionalizētās sociālās grupas iedalījums, kas noteica identitāti, bija sociālo grupu pārstāvju (ārsts-aprūpējamais) attiecību rezultātā konstruēts institucionālajos tekstos (šajā gadījumā - iestādes ziņojumos un albumā), to caur diskursiem nošķirot klasifikācijas un kategoriju ietvaros, kas reprezentēja sociālās un kultūras kategorijas saistībua 19. gadsimta otrās puses Latvijas teritorijāa. Identitātes veidošanu ietekmēja ne tikai noteiktā diagnoze, bet arī uzṇemšana iestādē, pēc kuras audzēkṇi bija pastāvīgā skolotāju un ārstu uzraudzībā. Informācija par audzēkṇiem, neskaitot personas datus un fotogrāfijas, ietvēra tekstuāli fiksētus novērojumus, kas raksturo katru gadījumu individuāli. No tā izriet, ka intelektuālā nespēja ir sociāli konstruēta, ${ }^{57}$ jo noteiktā diagnoze un raksturojums noteica aprūpējamā identitāti, kas tika dokumentāri fiksēta un reprezentēta informatīvajā telpā.

Medicīnas un pedagoǵijas jomu attīstība un institucionalizācija veicināja jaunu zināšanu rašanos un cirkulāciju sabiedrībā, izplatot informāciju par garīgo nespēju. Garīgās nespējas reprezentācija radīja priekšstatu par sociālās grupas pārstāvjiem, kam nepieciešama institucionāla apmācība un aprūpe, kas ir intelektuālo attīstību un izaugsmi veicinošs faktors. Tam kā pierādījums kalpoja izplatītā informācija ar konkrētiem gadījumu piemēriem. Albuma tekstuālajās piezīmēs tika norādītas diagnozes un minēti veselības traucējumi, taču vienlaikus arī uzsvērti pozitīvie rezultāti, turklāt fotogrāfijas radīja pozitīvu efektu, tādā veidā atbalstot iekḷaujošas sabiedrības veidošanos.

56 Patrick McDonagh, C. F. Goodey, \& Tim Stainton, "Introduction: the emergent critical history of intellectual disability" in Intellectual Disability: A Conceptual History, 1200-1900, ed. Patrick McDonagh, C. F. Goodey, \& Tim Stainton (Manchester: Manchester University Press, 2018), 2.

57 Ibid., 1. 


\section{Medicīnisko publikāciju aprite informatīvajā telpā}

Skatoties no mūsdienu perspektīvas, ir būtiski 19. gadsimta otrās puses zinātnes kultūras kontekstā vērst uzmanību uz iestādes publikāciju saturu un izplatību informatīvajā telpā, ko vēsturiskās attīstības gaitā ir skārušas izmaiņas. Tradicionālā izpratnē albumiem bija privāts raksturs - īpašnieki tajos apkopoja iegādāto fotogrāfiju kolekcijas vai personiskās tuvāko cilvēku fotogrāfijas, kas parādīja sabiedrības loku, ko vienoja radniecīgas vai draudzīgas saites. Albumus parasti glabāja mājās, kur tos arī apskatīja paši īpašnieki un rādīja tuvākajiem cilvēkiem. Citāda situācija bija ar iestādes albumu, kas ir pieskaitāms pie institucionālo, piemēram, uzraudzības, mācību, medicīnas vai citu veidu iestāžu albumu veida, kas bija raksturīgi 19. gadsimtā un 20. gadsimta pirmajā pusē.

Placa albuma pirmajā atvērumā ir veikala ielīme ar tekstu: "Magasin de la ville de Paris Riga. Rue d'Achat maison Hausmann bel étage", kas liecina, ka albumu izplatīja tirdzniecības ceḷā. To pārdeva tirgotājs K. F. Hausmans (C. F. Hausmann) savā veikalā Tirgoṇu ielā 17 (Kaufstraße, Rue d'Achat). ${ }^{58}$ Mūsdienās, kad tiek publicēta grāmata, notiek divu svarīgu interešu jomu - informācijas konfidencialitātes un publicēšanas tiesību - sadursme, jo psihiatrijas kā medicīnas nozares dati vienmēr ir sensitīvi un personiski, ${ }^{59}$ tādēl publikācijās netiek atklāti un mūsdienās, rakstot par savu pacientu, ārsta pienākums ir ļaut tam palikt anonīmam. Pretēji tam gan iestādes albumā, gan ziņojumos ir atklāti dati, kā rezultātā dažu audzēkņu identitāte netika slēpta, izņemot dažus gadījumus, kad ziņojumos bija norādīts tikai vārda pirmais burts un audzēkņi palika anonīmi. No tā var secināt, ka privātums un konfidencialitāte sabiedrības uztverē vēsturiski ir bijusi relatīva parādība un 19. gadsimta un pašreizējā zinātnes kultūra atšķiras.

Mūsdienās medicīniska satura informācija, kas nonākusi ārsta vai medicīnas personāla rīcībā, netiek izpausta trešajām personām un kḷūst par profesionālo noslēpumu. Ārstniecības personām konfidencialitātes un privātuma ievērošana ir profesionālā standarta daḷa un profesionālās ētikas prasība, kas neḷauj informāciju par ārstējamo personu izpaust

58 Rigasches Adreß-Buch für 1861, 27.

59 Robert I. Simon, Clinical Psychiatry and the Law, 2nd ed. (Washington, D. C.; London: American Psychiatric Press, 1992), 73. 
trešajām personām un liek respektēt privātās dzīves tiesības ar personas datu aizsardzību.

Savukārt publicētā albuma sākumdaḷā ir piezīmes, kurās norādīts audzēkṇu vārds, uzvārds, vecums, uzṇemšanas gads un datums, dzīvesvieta, veselības stāvoklis, diagnoze, tās cēlonis un audzēkṇu spēju un uzvedības raksturojums. Minētā informācija un fotogrāfijas ietver personu identifikatorus jeb datus, kas ḷauj identificēt personu. Pie tiem pieskaitāmi vārdi, ǵeogrāfiskie iedalījumi (mazāki par valsti) un portretu fotogrāfijas. ${ }^{60}$ Šādiem datiem, raugoties no mūsdienu medicīnas ētikas viedokḷa, kad “(p)ienākums nodrošināt veselības datu konfidencialitāti jau ilgstoši ir ticis atzīts par neatn,emamu ārsta profesionālo ētikas standartu”"61, gatavojot publiski pieejamus materiālus, būtu jābūt dzēstiem vai mainītiem, tādā veidā nodrošinot personas datu aizsardzību.

Atšķirībā no mūsdienu standartiem, kad medicīniska satura informācija tiek uzskatīta par konfidenciālu un kad tiek aizsargāti personas dati, 19. gadsimta otrajā pusē Latvijas teritorijā informācija par personām, kas pārstāv sociālo grupu ar garīgās attīstības traucējumiem, netika slēpta. Tas izskaidrojams ar to, ka “(m)edicīnas êtika var mainīties un arī mainās laika gaitā, attīstoties medicīnas zinātnei un tehnologijā̄m, kā arī mainoties sociālajām vērtībām (..).”62 Garīgās nespējas institucionalizācija bija attīstības sākumposmā, tādēḷ informācija par to tika mērḳtiecīgi aktualizēta, aicinot sabiedrību iesaistīties šāda tipa iestāžu darbības atbalstā un ienesot jaunās medicīnas un pedagoǵijas zināšanas sabiedrības apziņā. Tāpat ārstniecības un aprūpes iestāžu publikāciju atšķirīgā pieeja ir izskaidrojama ar vēlmi pamatot savas darbības efektivitāti, minot konkrētu gadījumu piemērus, kad audzēkṇi spējuši gūt izaugsmi mācību rezultātā. Sniegtā informācija un fotogrāfijas reprezentēja garīgās nespējas konceptu konkrētā laika izpratnē, tā pierādot institucionālās darbības nozīmi un efektivitāti sociālās aprūpes un speciālās izglītības kontekstā.

60 Gerald P. Koocher \& Patricia Keith Spiegel, Ethics in Psychology and the Mental Health Professions: Standarts and Cases, 4th ed. (Oxford: Oxford University Press, 2016), 178.

61 Agnese Gusarova, "Konfidencialitāte un personas datu aizsardzība veselības nozarē”, no Medicīnas tiesības, sagatavojis autoru kolektīvs S. Ašnevicas-Slokenbergas zinātniskajā redakcijā (Rīga: Tiesu namu aǵentūra, 2015), 350-351.

62 Džons R. Viljamss, Medicinnas ètikas rokasgrāmata, latviešu tekstu zin. red. Māris Baltiņš, 2. izd. (Rīga: Latvijas Ārstu biedrība, 2009), 25. 


\section{Secinājumi}

Kopš 19. gadsimta jaunās medicīnas zināšanas veicināja pielāgotu izglītības programmu un institucionāli organizētu sociālās aprūpes sistēmas veidošanos cilvēkiem ar garīgas attīstības traucējumiem. 1854. gadā Rīgā Frīdrihs Placs dibināja pirmo pedagoǵiski ārstniecisko iestādi, kurā uzṇēma cilvēkus ar dzirdes traucējumiem, kā arī ar garīgās attīstības un neirologiskiem traucējumiem. Iestādes uzraudzībā esošie aprūpējamie un apmācāmie ar garīgās attīstības vai citiem veselības traucējumiem kā atsevišķa sociāla grupa bija reprezentēta sabiedrībā. Garīgās nespējas reprezentācijas prakse ar fotogrāfijas izmantošanu ir uzskatāma par fenomenu 19. gadsimta otrās puses Latvijas teritorijas (toreizējās Krievijas Impērijas Vidzemes guberņas) medicīniskajā diskursā. Publikācijas bija garīgās nespējas diskursa forma, kas radīja jaunu naratīvu par garīgo nespēju un identitātes atspoguḷojumu. Placa iestādes albums un ziņojumi konstruēja garīgās nespējas konceptu atbilstoši konkrētā laika diagnožu klasifikācijai, kas arī ietekmēja iestādes apmācību darba organizāciju. Iestādē uzṇemtās personas tika iedalītas atsevišksās grupās, vadoties pēc veselības traucējumiem, kas ietvēra dažādu pakāpju garīgās attīstības un dzirdes traucējumus. Publiski pieejamā informācija par noteiktajām diagnozēm un personu raksturojumi veicināja sociāli plašāku nespējas koncepta izplatību un individualizāciju institucionālā līmen̄̄. Medicīniskajos diskursos sniegtie dati par personām konstruēja tām institucionalizētu identitāti, balstoties uz noteiktajām diagnozēm un raksturojumiem. Iestādē veiktie novērojumi rezultējās ar veselības stāvokḷa, intelektuālo spēju, uzvedības, īpašību un paradumu raksturojumu un noteikto slēdzienu reprezentāciju. Dokumentēto informāciju un portretus izmantoja administratīvam nolūkam, lai apkopotu informāciju par iestādē uzņemtajiem, kā arī kontrolei, lai salīdzinātu veselības stāvokli uzņemšanas laikā un vēlāk. Veselības stāvokḷa uzlabošanās, intelektuāla attīstība, patstāvība un pareiza uzvedība bija mērķis, uz ko tiecās iestāde ar pielāgotām apmācībām un aprūpi. Tuvošanos izvirzītajam mērķim pamatoja Frīdriha Placa piezīmes albumā, kurās pretstatīts audzēkṇu stāvoklis apmācību un aprūpes rezultātā un pirms tam, kā arī fotogrāfijas, kas atbilst 19. gadsimta portretu fotogrāfijas pieņemtās etiķetes un sabiedrības gaumes kritērijiem.

Konkrēto fotogrāfiju vizuālā retorika un iestādes darbība kopumā pauda iekḷaujošas sabiedrības ideju. Fotogrāfijas funkcija garīgās nespējas kontekstā bija atkarīga no fotogrāfiju albuma veidotāja - Frīdriha 
Placa - nolūka. Vizuāli albuma portreti neatšksiras no tradicionālajiem 19. gadsimta fotogrāfiju salonu cartes-de-visite portretiem, tomēr to institucionālais pielietojums izpaudās personu identificēšanā, iekḷaušanā dokumentācijā un kā pierādījums albuma autora tekstuāli paustajam vēstījumam. Iestādes albumā un ziņojumos bija sabiedrībai pieejama medicīniska satura informācija par anonīmiem vai identificējamiem subjektiem, neslēpjot personas datus un konfidenciālo medicīnas informāciju, kas mūsdienu situācijā ir atzīta par nepubliskojamu. Medicīniskās informācijas un fotogrāfijas publicitāte sabiedrībā atspoguḷo laika gaitā notikušās pārmaiņas medicīniskās informācijas ētikas izpratnē. Iestādes medicīnisko publikāciju aprite izskaidrojama ar to, ka iestāde bija jauna 'parādība' speciālās izglītības un aprūpes jomā, kas saṇēmusi darbības atḷauju un atbalstu. Tādēḷ iestādes publicētais albums un ziņojumi funkcionēja kā medijs informatīvajā telpā, kā rezultātā sabiedrība tika informēta par iestādes darbības efektivitāti, sasniegtajiem rezultātiem un iestādes audzēkṇiem.

\section{Origins of Special Education and Mental Health Care in Latvia in the Second Half of the Nineteenth Century}

\section{Abstract}

Representation practice of people with intellectual disability was a phenomenon in the nineteenth century medical discourse and photography in the territory of Latvia (then part of the Russian Empire). The album entitled "Idioten-Anstalt" is one of the oldest albums in the collection of the National Library of Latvia, published in 1862 in Riga. The author of the album is a teacher of deaf-mute children Friedrich Platz. He and his wife Therese Platz founded and managed the first establishment in Riga for people diagnosed with epilepsy and mental disability. The album contains numbered cartes-de-visite portraits of inmates, photographed by Baltic-German and German photographers, as well as textual notes, which reveal medical narrative of the period.

The aim of the paper is to identify the photographic practice in the establishment, the medical discourse of the institutional practice in visual and textual documentation and the ethical aspects from contemporary viewpoint 
(the opposition of a person's anonymity and publicity by visual displaying). The publicity of medical photography in society reflects the changes of institutional ethics over time. The album, distributed in selling market, functioned as a medium in an information space and represented mental disability to the public.

This paper was supported by the State research programme Latvia's Heritage and Future Challenges for the Sustainability of the State. The research results presented were obtained as part of the project Exploring documentary heritage for building synergies between research and society (No VPP-IZM-2018/1-0022).

Keywords: health care, special education, mental disability, medical photography, Therese Platz, Friedrich Platz.

\section{Stella Hermanovska}

Mag. sc. soc., Latvijas Nacionālā bibliotēka / National Library of Latvia 